\title{
Effect of the Addition of Nickel Powder and Post Weld Heat Treatment on the Metallurgical and Mechanical Properties of the Welded UNS S32304 Duplex Stainless Steel
}

\author{
Ali Tahaei ${ }^{1}$, Argelia Fabiola Miranda Perez ${ }^{2}$, Mattia Merlin ${ }^{1}$, Felipe Arturo Reyes Valdes ${ }^{2}$, Gian Luca Garagnani ${ }^{1}$ \\ 1 Università di Ferrara, Dipartimento di Ingegneria - ENDIF, Ferrara, Italia. \\ 2 Corporación Mexicana de Investigación en Materiales S.A. de C.V. - COMIMSA, Saltillo, Mexico.
}

Received: 25 Jan., 2016

Accepted: 10 June, 2016

E-mail: ali.tahaei@unife.it (AT)
This is an Open Access article distributed under the terms of the Creative Commons Attribution Non-Commercial License which permits unrestricted non-commercial use, distribution, and reproduction in any medium provided the original work is properly cited.

\begin{abstract}
In this research, the effect of the addition of nickel powder and the application of a post weld heat treatment (PWHT) on the welding properties of the UNS S32304 lean duplex stainless steel were investigated in order to improve the microstructure and mechanical properties. Nickel powder was directly poured inside the joint gap and mixed with the filler metal during the Gas Tungsten Arc Welding (GTAW) process; moreover, the solution heat treatment was performed at $1100{ }^{\circ} \mathrm{C}$ for $10 \mathrm{~min}$. The joints were characterized by optical microscopy (OM) and the evolution of the phase percentages in the different zones was studied by means of the image analysis technique. Tensile and hardness tests were carried out on the joints in order to evaluate the improvement of the mechanical properties. The results showed that both the addition of nickel powder during the welding process and the post weld heat treatment made it possible to improve the mechanical properties of the weld joints. PWHT had the best effect in restoring the equal percentage of ferrite and austenite compared to the addition of nickel powder.
\end{abstract}

Key-words: Duplex stainless steel; GTAW process; Nickel powder; PWHT; Microstructure.

\section{Efeito da Adição de Pó de Níquel e do Tratamento Pós Soldagem nas Propriedades Metalúrgicas do Aço Inoxidável Duplex UNS S32304 Soldado}

Resumo: No presente estudo, foi investigado o efeito da adição de pó de níquel e a aplicação de um tratamento térmico pós-soldagem (PWHT) nas propriedades de soldagem do aço inoxidável lean duplex UNS S32304, a fim de melhorar a microestrutura e as propriedades mecânicas. Pó de níquel foi diretamente vertido na abertura da junta e misturado com o metal de adição durante o processo de soldagem a arco com eletrodo de tungsténio e proteção gasosa (GTAW). Além disso, o tratamento térmico foi estabelecido em $1100{ }^{\circ} \mathrm{C}$ por $10 \mathrm{~min}$. As juntas foram caracterizadas por microscopia óptica (MO) e a evolução das percentagens de fase nas diferentes zonas foi estudada por meio da técnica de análise de imagem. Os ensaios de tração e de microdureza foram realizados, a fim de avaliar a melhoria das propriedades mecânicas das juntas. Os resultados mostraram que tanto a adição de pó de níquel durante o processo de soldagem e o tratamento térmico pós-soldagem permitiram melhorar as propriedades mecânicas da junta soldada. PWHT mostrou o melhor efeito em restaurar a percentagem igual de ferrita e austenita comparado com a adição de pó de níquel.

Palavras-chave: Aços Inoxidáveis Duplex; GTAW; Pó de níquel; PWHT; Microestrutura.

\section{Introduction}

Duplex stainless steels, due to a roughly equal percentage of the ferrite and austenite phases, are characterized by high mechanical strength and stress corrosion cracking properties if compared with ferritic and austenitic steels. Moreover, they show higher toughness and plasticity than martensitic steels [1-5]. Due to their unique properties, these stainless steels present some advantages with respect to monophase stainless steels [6] and have many applications in different sectors such as the food, petrochemical, oil\&gas and marine industries. Different welding methods can be applied to duplex stainless steels for the production of a range of equipment and structures. Normally, fusion-welding processes can cause damage to the equal percentage of the ferrite and austenite phases, which is responsible for their good engineering properties [7,8]. Many authors have studied 
different solutions to restore the equal percentages of the ferrite and austenite phases as well as solutions to avoid precipitation of the detrimental intermetallic compounds such as the sigma $(\sigma)$, chi $(\chi)$ and nitride phases after the welding processes [9,10]; the critical temperatures for the formation of these phases are between 650 and $900{ }^{\circ} \mathrm{C}$. Lippold and Koseki [11] suggested limiting the heat input during welding of the duplex stainless steels in the range of $0.5-2.0 \mathrm{~kJ} / \mathrm{mm}$, so that formation and precipitation of the deleterious intermetallic phases can be avoided [12-14].

Some methods were suggested to improve the microstructure and the mechanical properties of duplex welded joints, such as adding nickel powder or nitrogen gas and/or applying appropriate post weld heat treatment. Nickel is a strong austenite stabilizer element, which makes it possible to increase the percentage of austenite in the microstructure after welding. Pilhagen and Sandstrom [15], Muthupandi et al. [7] and Migiakis and Papadimitriou [16] investigated the effects of the addition of nickel on the microstructure and the mechanical properties of duplex and super duplex welded joints. They observed improvements in the phase balance and toughness properties after the addition of nickel and nitrogen. Post weld heat treatment (PWHT) can be performed on the welded joints to restore the equal percentages of the phases by also inducing the decrease in the segregation of alloying elements, which mainly occurs during solidification. It was reported that PWHT leads to an improvement in corrosion resistance and avoids the formation of brittle intermetallic compounds by precisely controlling the annealing temperature and the cooling rate. Generally, a high annealing temperature followed by water quenching reduces the risk of formation in the intermetallic phases [9,10]. Badji et al. [1] investigated the effect of the annealing temperature on the phase percentages after welding. They found that, when the annealing temperature is increased, the amount of intermetallic phases decreases and roughly equal percentages of ferrite and austenite remain in the microstructure. Moreover, they proposed $1100^{\circ} \mathrm{C}$ as an optimum annealing temperature. Garzon and Ramirez [17] worked on the effect of the heat treatment on the microstructure of the welded UNS S32304 stainless steel. Despite there being many separate investigations in the literature on the addition of different alloying elements and/or different heat treatments, there is still a lack of information about what is considered the best method for improving the weld quality of duplex stainless steels. Consequently, this study focuses on the combination of the addition of nickel powder during welding of the UNS S32304 lean duplex stainless steel with the post weld heat treatment.

\section{Experimental Procedure}

\subsection{Materials and welding method}

In this investigation, UNS S32304 duplex stainless steel plates with dimension of $50 \mathrm{~mm} \times 50 \mathrm{~mm} \times 3 \mathrm{~mm}$ were welded by the manual gas tungsten arc welding (GTAW) process, using the ER2209 as filler material (AWS A5.9). Table 1 shows the chemical compositions of the base and filler materials.

Before welding, the edges of the plates were cleaned thoroughly with alcohol to remove all dust and contaminates. The welding was performed perpendicular to the rolling direction of the plates. Due to the small thickness of the plates $(3 \mathrm{~mm}$ ), a butt joint with a $2.4 \mathrm{~mm}$ gap between the two plates was used for all conditions. The welding parameters were selected according to Table 2 .

Table 1. Chemical compositions (wt\%) of the base metal and the filler material.

\begin{tabular}{lccccccccc}
\hline \multicolumn{1}{c}{} & & & \multicolumn{7}{c}{ Elements } \\
Material & $\mathbf{C}$ & $\mathbf{C r}$ & $\mathbf{N i}$ & $\mathbf{M o}$ & $\mathbf{M n}$ & $\mathbf{S i}$ & $\mathbf{C u}$ & $\mathbf{N}$ & $\mathbf{F e}$ \\
UNS S32304 & 0.02 & 23.47 & 5.05 & 0.36 & 1.37 & 0.48 & 0.31 & - & Bal. \\
ER2209 & 0.01 & 22.8 & 8.5 & 3.1 & 1.6 & 0.4 & 0.16 & 0.16 & Bal. \\
\hline
\end{tabular}

Table 2. Welding parameters.

\begin{tabular}{ccccccc}
\hline $\begin{array}{c}\text { Current } \\
\text { (A) }\end{array}$ & $\begin{array}{c}\text { Voltage } \\
\text { (V) }\end{array}$ & $\begin{array}{c}\text { Travel speed } \\
\text { (mm/min) }\end{array}$ & $\begin{array}{c}\text { Filler material } \\
\text { (AWS A5.9) }\end{array}$ & $\begin{array}{c}\text { Heat input } \\
\text { (kJ/mm) }\end{array}$ & Shielding gas & $\begin{array}{c}\text { Gas flow } \\
\text { (I/min) }\end{array}$ \\
\hline 80 & $12-15$ & $50-70$ & ER 2209 & 1.14 & $\operatorname{Ar} 99.99 \%$ & 12 \\
\hline
\end{tabular}


Considering the welding process, two different conditions were considered in this study. In particular, in the first condition, the stainless steel was welded only by using the filler material, while in the second condition nickel powder with spherical morphology and a diameter range of $150 \pm 60 \mu \mathrm{m}$ was pre-poured manually into the joint gap before welding, as shown in Figure 1.

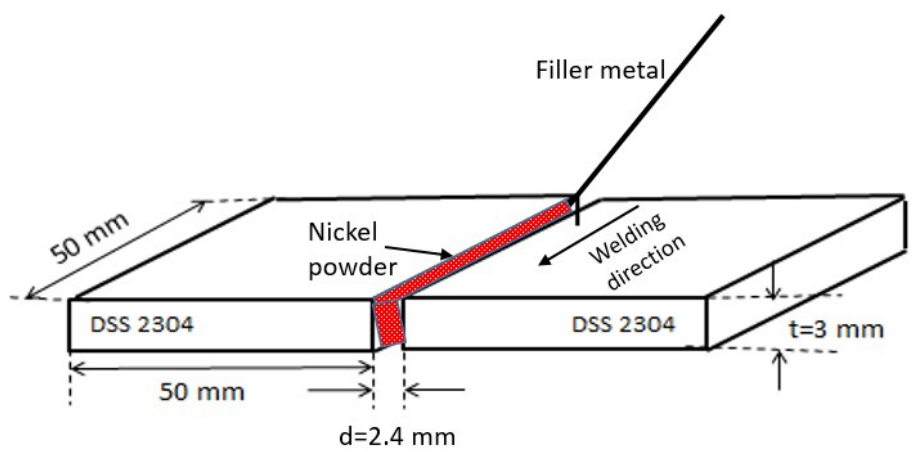

Figure 1. Layout of the joint with addition of nickel powder.

Considering the subsequent microstructural and mechanical investigations of the joints, two different metallurgical conditions were considered after welding. Half of the joints were studied in the as-welded condition, while the other half was subjected to post weld heat treatment at $1100^{\circ} \mathrm{C}$ for $10 \mathrm{~min}$ followed by water quenching. This temperature was selected because it is higher than the solubilization temperature of all deleterious intermetallic phases and is recommended by other authors in the literature. Moreover, the metallurgical analyses of the base metal in the as-received condition and in the heat-treated condition according to the as-mentioned parameters were considered as a reference. All the different conditions are summarized in Table 3 with the designation of the investigated samples.

Table 3. Designation of samples and welding conditions.

\begin{tabular}{ll}
\hline \multicolumn{1}{c}{ Sample name } & \multicolumn{1}{c}{ Conditions } \\
BM & Base metal \\
BMP & Base metal-after heat treatment \\
F & Welded just with filler metal \\
FP & Welded with filler-PWHT \\
FNi & Welded with filler-adding nickel powder \\
FNiP & Welded with filler-adding nickel powder-PWHT \\
\hline
\end{tabular}

\subsection{Metallurgical investigation and mechanical testing}

A metallurgical investigation was performed based on conventional laboratory procedure. Cross sections, including base metal, heat-affected and fusion zones, were cut from all the joints and embedded in a thermoset resin. All samples were then subjected to the standard metallographic procedures in order to prepare the metallic surfaces to the subsequent metallurgical investigations. The Beraha reagent $\left(50 \mathrm{ml} \mathrm{H}_{2} \mathrm{O}, 50 \mathrm{ml} \mathrm{HCl}, 1 \mathrm{~g} \mathrm{~K}_{2} \mathrm{~S}_{2} \mathrm{O}_{5}, 10 \mathrm{~g} \mathrm{NH} \mathrm{F}_{4}\right.$. HF) [18] was used for etching and revealing the microstructure of all the samples. The Leica MF4M optical microscope equipped with the A4I image software and the Zeis EVO EMA 15 scanning electron microscope with an EDS microprobe were used. The percentages of the phases were calculated by image analysis techniques. For the evaluation of the mechanical properties, hardness and tensile tests were performed on the joints. In particular, Vickers hardness profiles were performed on the samples to evaluate the evolution of hardness from the base metal to the fusion zone, through the heat affected zone. The Future Tech microhardness machine with a load of $1 \mathrm{~kg}$ was used for the hardness measurements. To investigate the tensile properties of the samples, according to the ASTM E8M standard, sub-size tensile samples were prepared and tested by a Tinius Olsen 60 machine. 


\section{Results and Discussion}

\subsection{Microstructure}

Before carrying out the microstructural inspections, no evidence of macroscopic defects was detected in the joints. As can be seen in Figure 2, the microstructure of the base metal in the as-received condition (BM) consists of roughly equal percentages of ferrite and austenite.

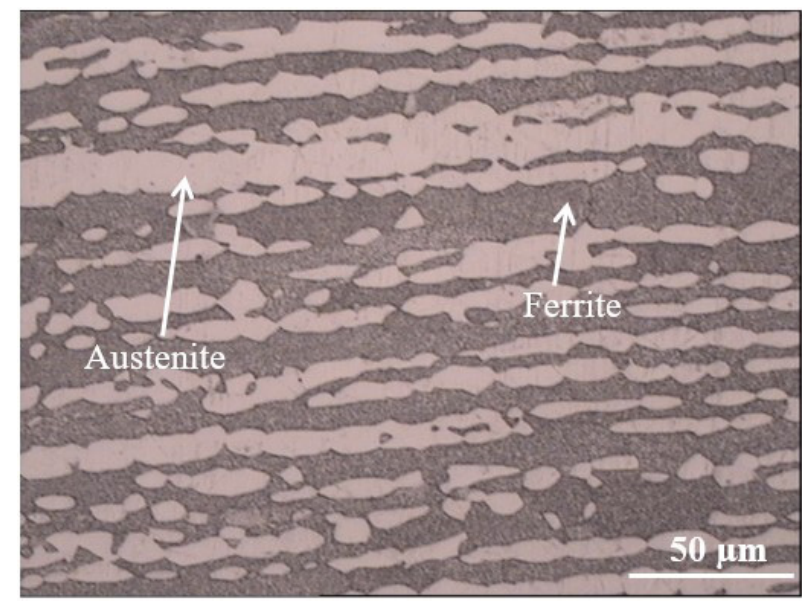

Figure 2. Optical micrograph of the UNS S32304 base metal.

The microstructures of the different zones in samples F and FP are depicted in Figure 3 . Figure $3 a, b$ shows the transition zone from the base metal to the fusion zone before and after PWHT. Interpretation of the microstructure of the heat-affected zone (HAZ) is difficult because it strongly depends on the microstructure of the base metal, the peak temperature, the holding time at peak temperature and the heating and cooling rates [19]. The austenite phase in the DSS weld zones is generally formed from ferrite in three different modes: allotriomorphic austenite at the ferrite grain boundaries (GB), widmanstätten austenite side-plates (WS) inside the grains, and intergranular austenite (IG) [20,21]. The microstructure of HAZ in sample F (Figure 3c) mainly consists of large ferrite grains with intergranular austenite, grain boundary austenite and widmanstätten austenite side plates, which mainly nucleated at the grain boundaries; small secondary austenite was formed and distributed inside the ferrite matrix. After PWHT (Figure 3d), the morphology of the austenite changed to an intergranular and spheroidal shape, together with an increase in the percentages of austenite. The fusion zone of sample $\mathrm{F}$ (Figure $3 \mathrm{e}$ ) consists of large elongated and columnar austenite grains, distributed in the ferrite matrix. After PWHT (Figure 3f), grain refining and precipitation of the austenite inside the ferrite matrix occur and the morphology of austenite changes and becomes smoother and globular.

Figure 4 shows the microstructure of the FNi and FNiP samples. In Figure $4 a, b$, the microstructures at the interface between the fusion zone and the HAZ before and after PWHT are shown, respectively. The HAZ of the sample FNi (Figure 4c) mainly consists of separated intergranular austenite laths in the ferrite matrix. After PWHT (Figure 4d), the amount of austenite increases and becomes more globular and uniformly distributed in the matrix. The weld zone of sample FNi (Figure 4e) consists of a higher amount of coarse widmanstätten austenite, distributed in the ferrite matrix. After PWHT (Figure 4f), the microstructure becomes finer and smoother, characterized by an increased amount of austenite. This microstructure is in agreement with the results of Zhang et al. [9]. In order to consider the change in the chemical analysis induced by the addition of nickel powder, EDS analysis was performed on the fusion zone of different samples. The results are collected in Table 4 and, as it is clear, the addition of nickel powder determines a greater increase in the nickel content in the fusion zone. After PWHT, a little decrease in this element can be detected, probably due to the occurrence of diffusion processes in the weld zone. 


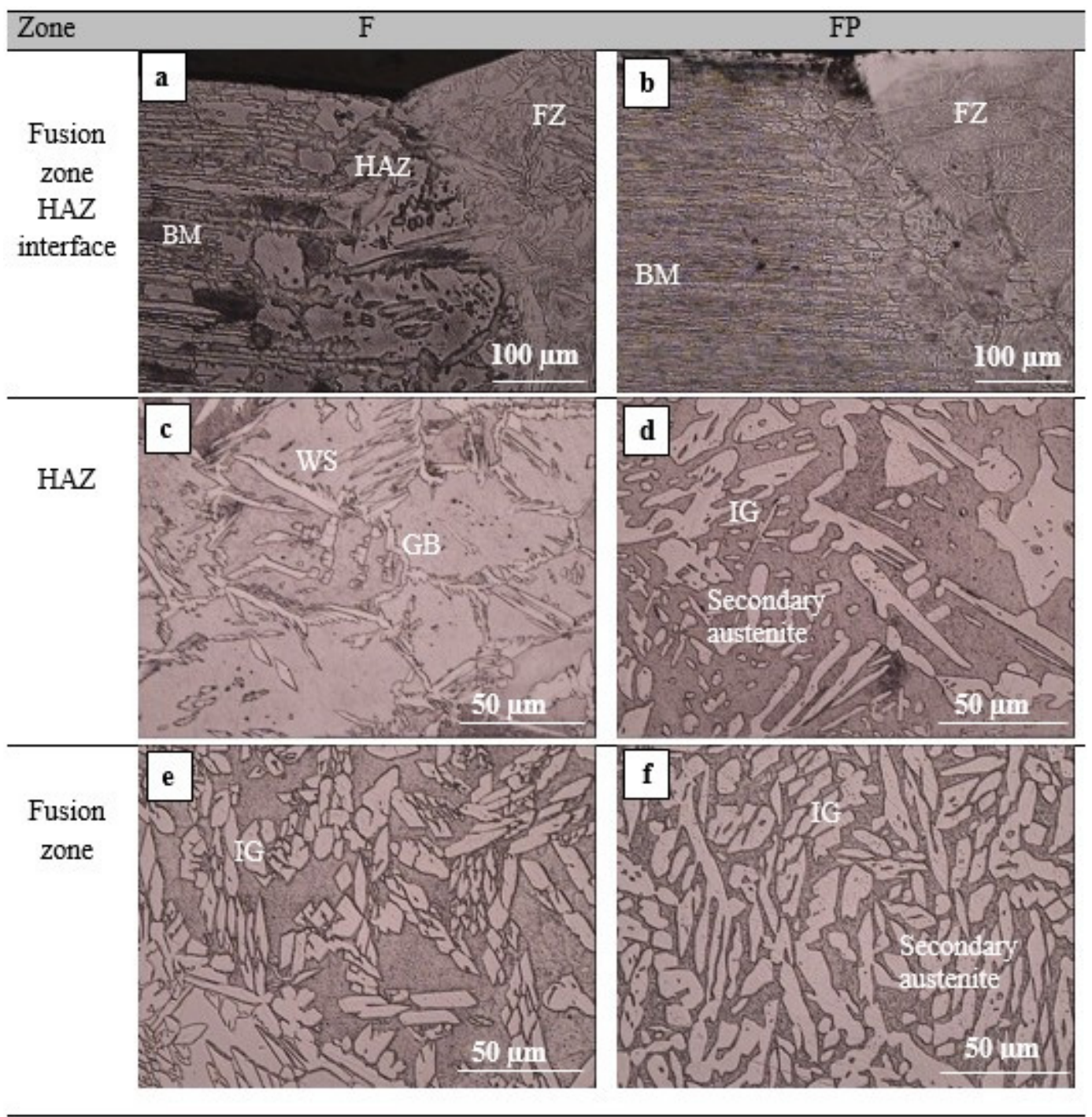

Figure 3. Microstructure of the weld zone of samples F (welded by filler) and FP(welded by filler and PWHT).

Table 4. EDS analysis (wt\%) of the fusion zone in different conditions.

\begin{tabular}{ccccccc}
\hline Sample & Cr & Ni & Mo & Mn & Si & Fe \\
F & 23.04 & 7.51 & 2.75 & 1.63 & 0.53 & Bal. \\
FP & 23.89 & 6.13 & 2.45 & 1.56 & 0.55 & Bal. \\
FNi & 21.9 & 12.49 & 2.28 & 1.46 & 0.73 & Bal. \\
FNiP & 23.07 & 8.03 & 2.09 & 1.57 & 0.74 & Bal. \\
\hline
\end{tabular}

\subsection{Determination of phase percentage}

Generally, the balance between percentages of ferrite and austenite phases can be achieved by controlling the chemical composition of the base metal and selecting an appropriate filler material. The filler material should contain austenite stabilizer elements such as nickel and nitrogen [22]; Wang et al. [5] found that the effect of nickel is more important than other elements for austenite formation. The quantitative evaluation of the percentages of both ferrite and austenite phases in the different zones of the joints was performed based on microstructural investigations and by using an image analyzer software. Five images were taken for each zone (BM, HAZ and fusion zone) and the surface fractions of each phase were calculated in accordance with the ASTM E1245 standard (see Figure 5). 


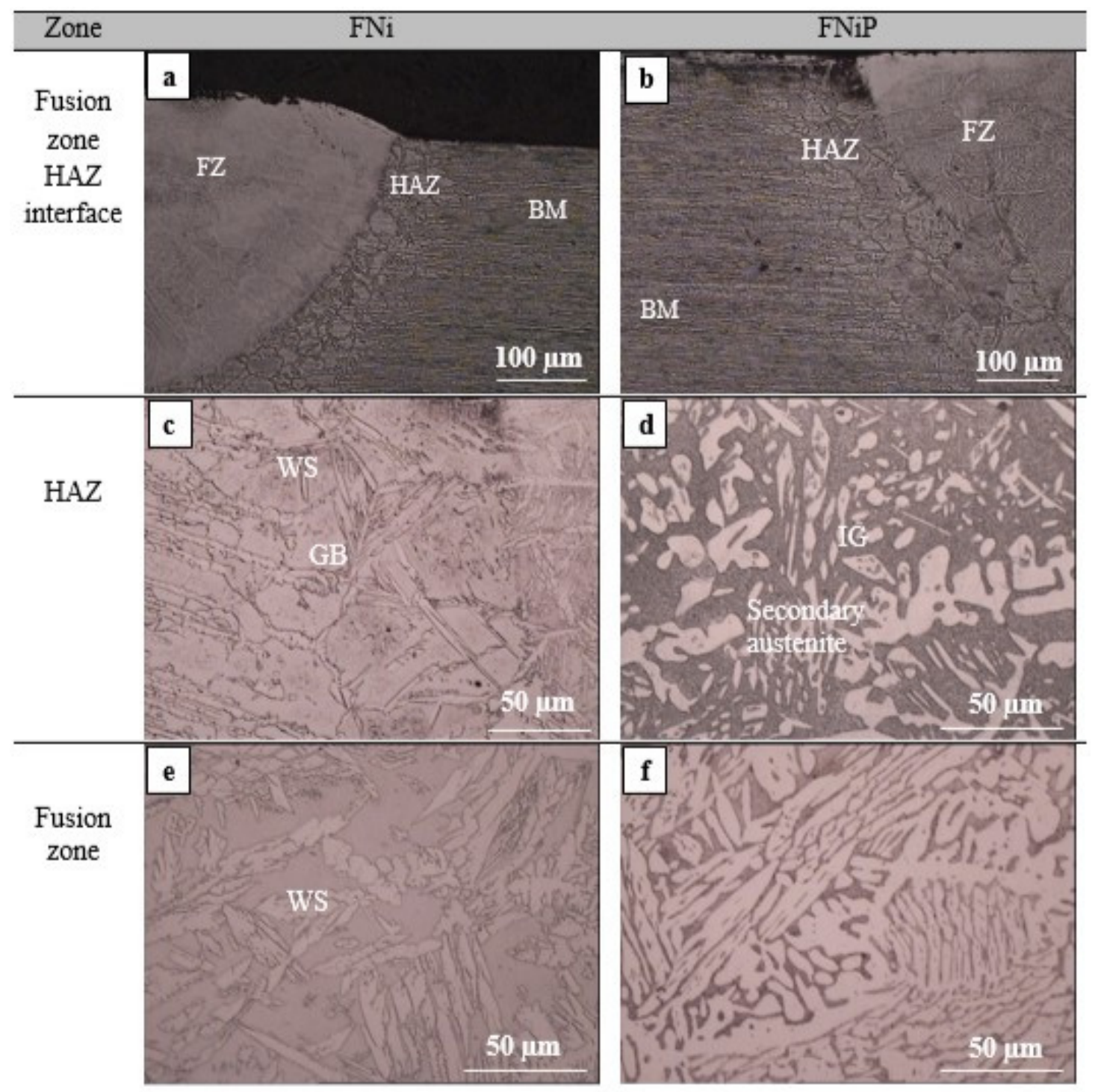

Figure 4. Microstructure of the weld zones of samples FNi (welded by Ni powder) and FNiP (welded by Ni powder and PWHT).
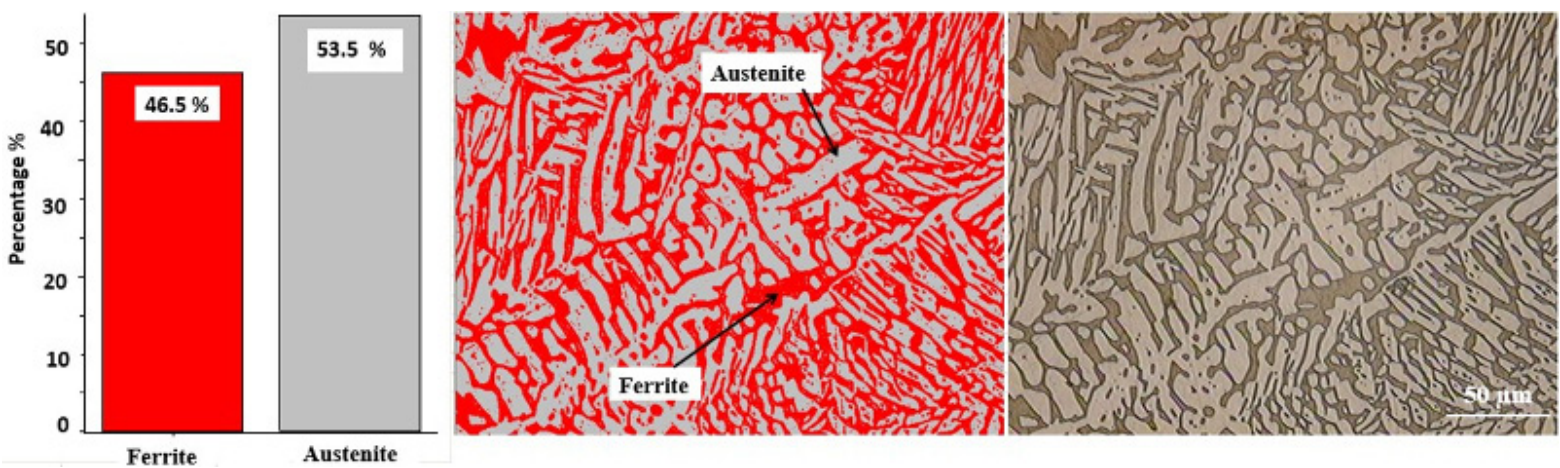

Figure 5. Example of phase percentage determination. 
Effect of the Addition of Nickel Powder and Post Weld Heat Treatment on the Metallurgical and Mechanical Properties of the Welded UNS S32304 Duplex Stainless Steel

In Figure 6, the results of the calculated phase percentages are shown by means of a histogram. As can be seen, the percentages of austenite in the HAZ of all the samples range between 22 and $33 \%$, which is in agreement with the results of Sieurin and Sandstrom [23]. Moreover, in the fusion zone, the concentration of ferrite is less than that of the austenite, probably due to the higher amount of austenite stabilizer elements such as nickel in the filler metal or the addition of powder in the joint [7]. The main changes in the microstructure occur after PWHT, due to the fact that roughly equal amounts of austenite and ferrite have been restored in the microstructure. In particular, the percentage of austenite after PWHT increases to around $42 \%$ in $\mathrm{HAZ}$ and $52-60 \%$ in the fusion zone.

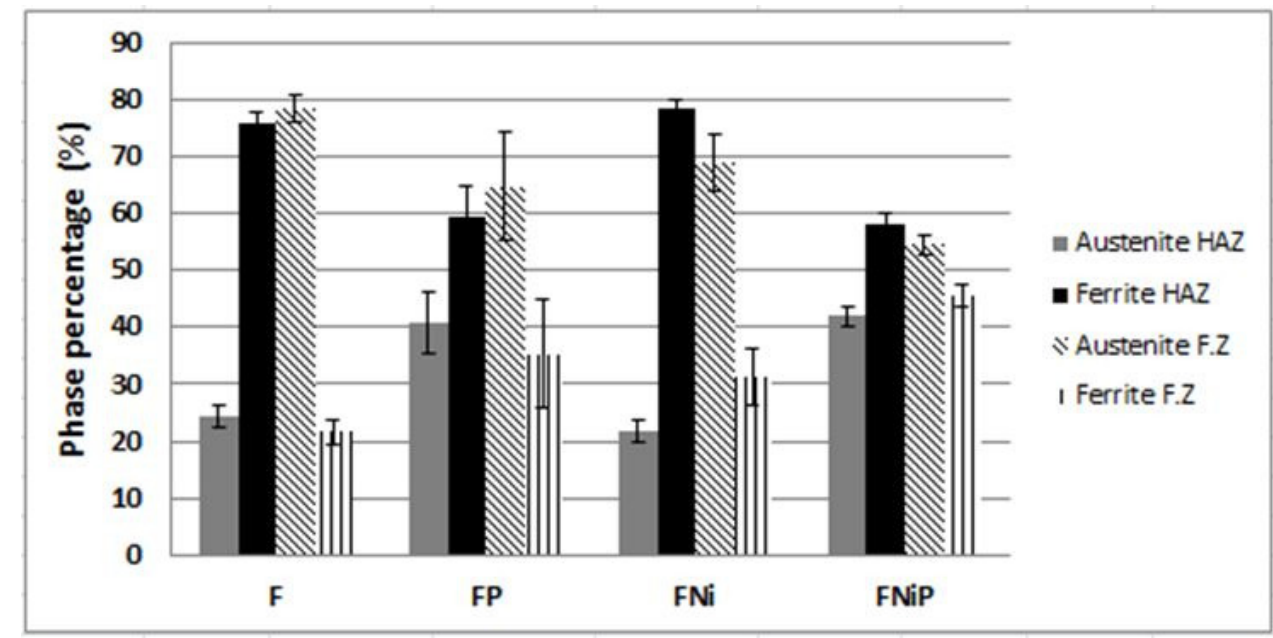

Figure 6. Diagram for comparison of ferrite/austenite percentage in fusion zone (FZ) and HAZ.

This means that PWHT has a significant effect on the microstructure of the joint. In addition, based on the results of the base metal before and after PWHT, it is clear that the percentage of austenite phase increases after PWHT and that the amount of both phases becomes roughly equal (48\%Ferrite-52\%Austenite). This means that appropriate results were obtained, because for most industrial applications and piping inspection procedures, austenite contents lower than 25-30\% are considered unacceptable [24-26]. Moreover, according to Hagen [27], the optimum percentage of austenite required to reach an appropriate combination of corrosion resistance and mechanical properties should be in the range of 40 and $60 \%$. Samples $\mathrm{F}$ and $\mathrm{FNi}$ show the maximum differences between the ferrite and austenite phases in both the HAZ and fusion zone; samples FP and FNiP show the best results in both the HAZ and fusion zone. This means that the effect PWHT has on changing the phase is more efficient than the addition of alloying elements. This result is in agreement with the investigation of Liu et al. [28].

\subsection{Hardness profiles}

Typical hardness profiles were performed through the base metal, heat affected zone and fusion zone of each welded sample. The hardness of the base metal was measured in the range of 240-250 HV1. The results of the hardness measurements for all samples are specified in Figure 7 . In the as-welded sample (F), the value of hardness is fairly uniform (240-260 HV1) through the different zones; also by applying the PWHT, no changes in the value of hardness were detected which is in agreement with the results of Udayakumar et al. [29] and Mourad et al. [4]. This could be due to i) the close chemical composition of the base metal and filler metal and ii) the absence of precipitation of any intermetallic phases in the microstructure. In sample FNi, the hardness values in the fusion zone are higher than in the base metal (260-270 HV1 compared with 240-250 HV1): this can be justified by considering the higher amount of rough widmanstätten austenite in the microstructure. Sample FNiP shows a little decrease in hardness of the fusion zone (220-240 HV1) compared to sample FNi. 


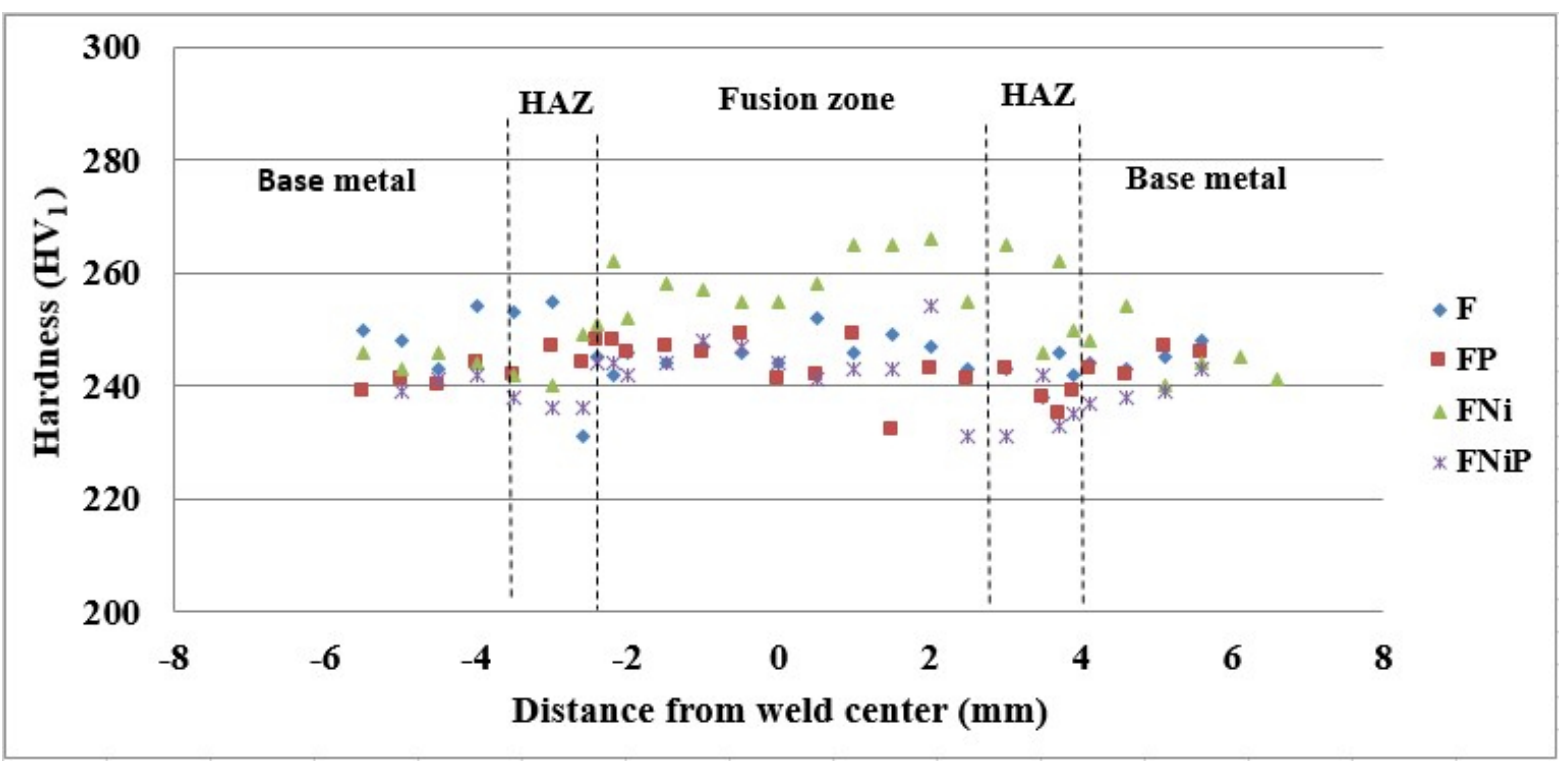

Figure 7. Hardness profile of samples F, FP, FNi, FNiP.

These results are in agreement with the microstructural analyses, which confirm the formation of austenite with finer, smoother and globular morphology after PWHT; moreover, an additional effect could be due to the stress relieving in the weld zone [7]. Due to the small area of phases, measuring the exact value of hardness for ferrite and austenite with conventional methods is difficult. Therefore, the values of macrohardness, which include both phases, are not so different [7,30]. Based on the obtained results, as mentioned above, any specific differences in the hardness of the weld zones were not observed. It showed that differences between the percentage of the ferrite and austenite phases do not have so much of an effect on the hardness value, which is in agreement with the results of Muthupandi et al. [7] and Mourad et al. [4]. Finally, it should be mentioned that, all obtained hardness was less than the maximum value of $350 \mathrm{HV} 1$, which is the maximum allowable value for industrial applications [31].

\subsection{Tensile tests}

Tensile tests were performed to evaluate the static mechanical properties of the joints by considering the effect of both Ni addition and PWHT. Subsize tensile samples were cut and machined from the weld joints according to the ASTM E8 standard [32]. In Table 5, the results of the tensile tests are collected for all the samples. Sample FP shows a decrease in Tensile strength (UTS) of about $10 \%$ compared to sample FP, also sample FNiP shows a slight drop (about 2\%) in the value of the UTS with respect to sample FNi. After PWHT, mainly microstructural softening, internal stresses release and reduction of dislocation density occur. Consequently, tensile strength decreases, but despite this reduction the value of strength is more than the minimum acceptable value of the base metal. The low ductility of the sample $\mathrm{F}$ can be attributed to the widmanstätten morphology of the austenite and the presence of the secondary austenite in the HAZ and fusion zone [16].

Table 5. Results of the tensile tests.

\begin{tabular}{cccccc}
\hline Sample & $\begin{array}{c}\text { Yield strength Y.S } \\
(\mathbf{M P a})\end{array}$ & $\begin{array}{c}\text { Tensile Strength } \\
\text { U.T.S }(\mathbf{M P a})\end{array}$ & $\begin{array}{c}\text { Elongation } \\
\mathbf{( \% )}\end{array}$ & Y.S/U.T.S & Location of fracture \\
F & 483 & 695 & 21 & 0.69 & Fusion zone \\
FP & 376 & 619 & 22 & 0.6 & Fusion zone \\
FNi & 494 & 717 & 22 & 0.68 & Base metal \\
FNiP & 443 & 697 & 35 & 0.63 & Base metal \\
BM & 451 & 712 & 39 & 0.63 & Base metal \\
\hline
\end{tabular}


By considering the results of the microstructure analysis, phase determination and tensile tests, it can be said that the effect of PWHT is mainly on the improvement of the microstructure to restore equal percentages of the ferrite and austenite without significant changes to the mechanical properties. For samples $F$ and FP, the value of elongation was lower than the minimum standard value. For the sample FNiP, a significant increase in elongation was observed and this is also confirmed by the result of the hardness tests that showed a decrease trend compared to the untreated sample. The results also confirm that nickel is an effective element for solid solution strengthening and it causes an increase in the yield and tensile strength of the samples. Images of the complete tensile test samples after fracture are shown in Figure 8. The side view macrographs of the fractured samples obtained by means of stereomicroscope are presented in Figure 9; sample F and FP were broken in the weld zone, while samples FNi and FNiP were broken from the base metal, this means that the effect of
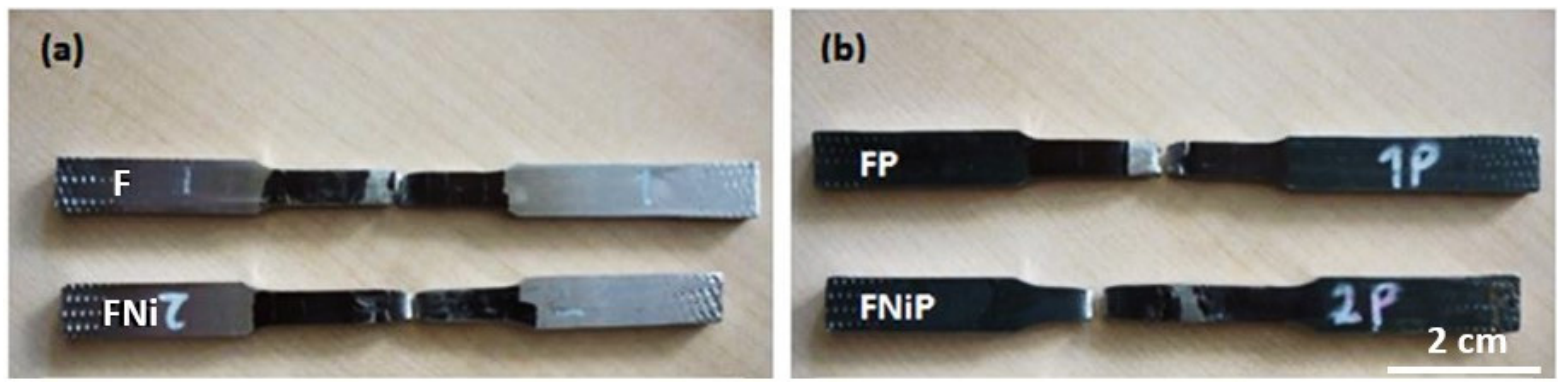

Figure 8. Images of the tensile samples (a) without PWHT and (b) with PWHT.
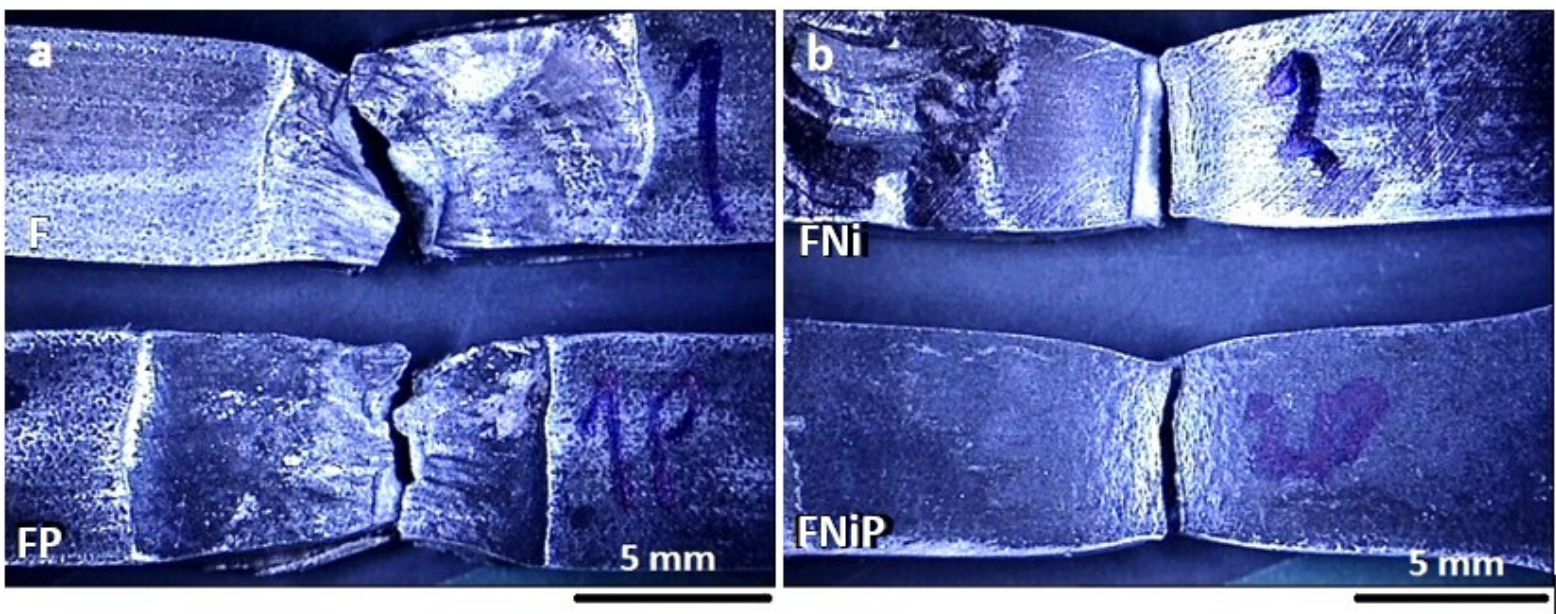

Figure 9. Macrographs of the fracture surface of samples (a) F, FP and (b) FNi, FNiP.

the addition of nickel to increase the tensile properties is higher than the PWHT. Fracture surface analysis was performed for all the samples and the relevant images are shown in Figure 10. Microscopically, for all the samples, the fracture is ductile with a visible necking area. After applying the PWHT, the fracture remains ductile but the dimples become larger. Detailed and deep analysis of fracture surfaces will be presented by the same authors in another paper. 

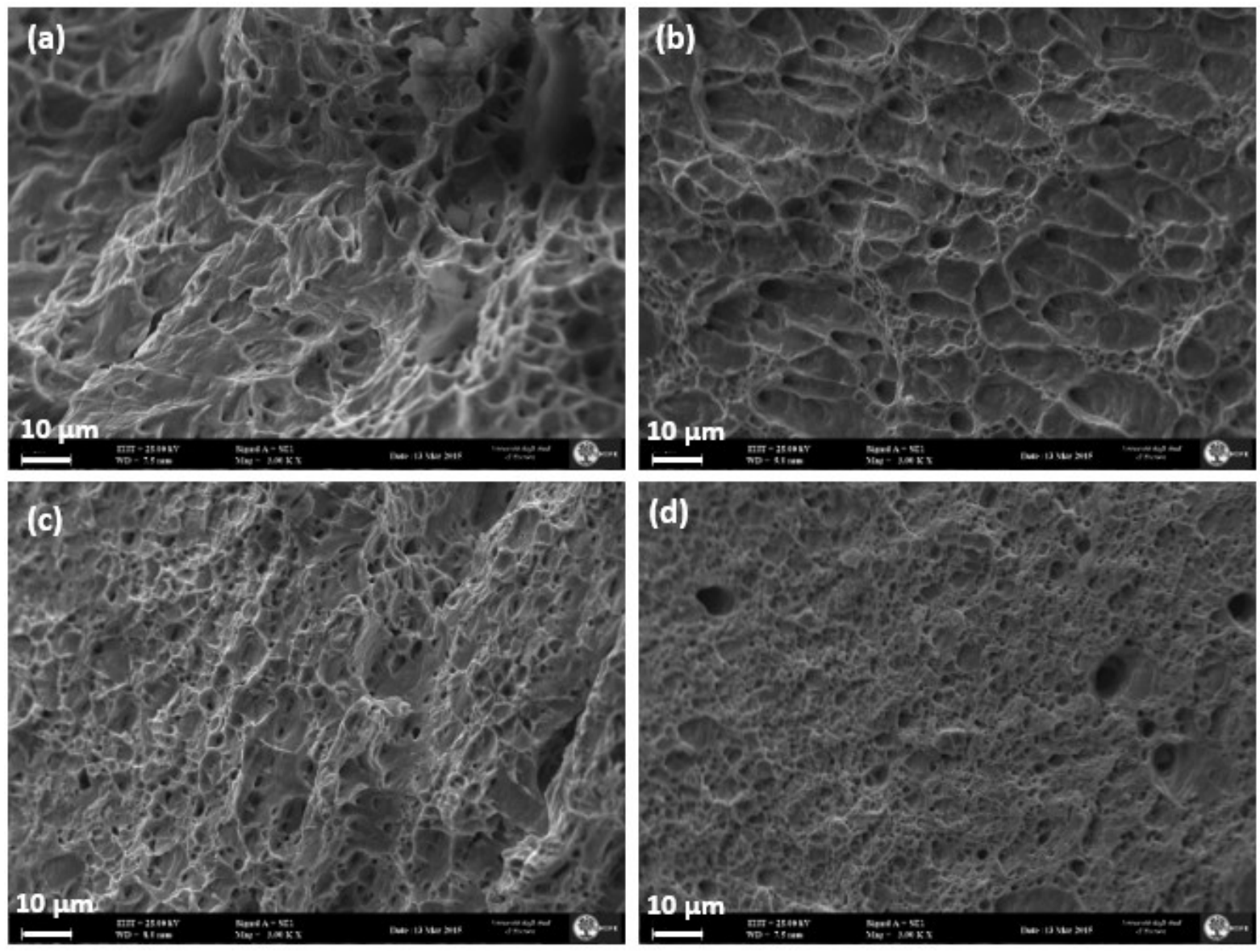

Figure 10. SEM fracture surface of samples (a) F; (b) FP; (c) FNi and (d) FNiP.

\section{Conclusions}

In this research, we studied the effect of the addition of nickel powder and the application of post weld heat treatment (PWHT) on the microstructural and mechanical properties of the UNS S32304 lean duplex stainless steel, welded by manual GTAW process. The following conclusions can be made from the experimental investigation:

- Successful and sound welds were obtained by using filler metal ER2209 to weld the UNS S32304 duplex stainless steel by means of the GTAW process.

- After welding, the percentages of ferrite and austenite in the fusion zone were drastically changed. Equal percentages of ferrite and austenite were restored by applying short time $\mathrm{PWHT}$, performed at $1100{ }^{\circ} \mathrm{C}$ for $10 \mathrm{~min}$, followed by water quenching.

- In the samples welded by only using the filler metal, no significant variation in the hardness profiles was detected due to the PWHT with respect to the as-welded condition. Conversely, in the samples welded with the addition of nickel powder, a small decrease in hardness was found after PWHT, which is perhaps due to the best and most homogeneous distribution of the phases.

- When comparing the obtained results, the addition of nickel powder has little effect on the increase in hardness in the fusion zone. The improvement of the microstructure and mechanical properties obtained by performing the PWHT is higher than with the addition of nickel powder.

- Among all the welding conditions, the joint with the addition of nickel powder followed by PWHT showed the best microstructural properties and the highest mechanical properties. 
Effect of the Addition of Nickel Powder and Post Weld Heat Treatment on the Metallurgical and Mechanical

Properties of the Welded UNS S32304 Duplex Stainless Steel

\section{Acknowledgements}

Ali Tahaei gratefully acknowledges IUSS 1391 of the University of Ferrara (Unife-ENDIF) for its financial support. Special thanks should also be given to CONACYT for both its financial and experimental support during the internship at Corporación Mexicana de Investigación en Materiales (Comimsa).

\section{References}

[1] Badji R, Bouabdallah M, Bacroix B, Kahloun C, Belkessa B, Maza $\mathrm{H}$. Phase transformation and mechanical behaviour in annealed 2205 duplex stainless steel welds. Materials Characterization. 2008;59(4):447-453. http://dx.doi.org/10.1016/j. matchar.2007.03.004.

[2] Badji R, Bacroix B, Bouabdallah M. Texture, microstructure and anisotropic properties in annealed 2205 duplex stainless steel welds. Materials Characterization. 2011;62(9):833-843. http:// dx.doi.org/10.1016/j.matchar.2011.06.001.

[3] Luo J, Dong Y, Li L, Wang X. Microstructure of 2205 duplex stainless steel joint in submerged arc welding by post weld heat treatment. Journal of Manufacturing Processes. 2014;16(1):144148. http://dx.doi.org/10.1016/j.jmapro.2013.06.013.

[4] Mourad A-HI, Khourshid A, Sharef T. Gas tungsten arc and laser beam welding processes effects on duplex stainless steel 2205 properties. Materials Science and Engineering A. 2012;549:105113. http://dx.doi.org/10.1016/j.msea.2012.04.012.

[5] Wang S, Ma Q, Li Y. Characterization of microstructure, mechanical properties and corrosion resistance of dissimilar welded joint between 2205 duplex stainless steel and $16 \mathrm{MnR}$. Materials \& Design. 2011;32(2):831-837. http://dx.doi.org/10.1016/j. matdes.2010.07.012.

[6] Bhattacharya A, Singh PM. Stress corrosion cracking of welded 2205 duplex stainless steel in Sulfide-containing caustic solution. Journal of Failure Analysis and Prevention. 2007;7(7):371-377. http://dx.doi.org/10.1007/s11668-007-9069-6.

[7] Muthupandi VP, Srinivasan B, Shankar V, Seshadric SK, Sundaresanc $S$. Effect of nickel and nitrogen addition on the microstructure and mechanical properties of power beam processed duplex stainless steel (UNS 31803) weld metals. Materials Letters. 2005;59(18):2305-2309. http://dx.doi. org/10.1016/j.matlet.2005.03.010.

[8] Capello E, Chiarello P, Previtali B, Vedani M. Laser welding and surface treatment of a $22 \mathrm{Cr} / 5 \mathrm{Ni} / 3 \mathrm{Mo}$ duplex stainless steel. Materials Science and Engineering A. 2003;351(1-2):334-343. http://dx.doi.org/10.1016/S0921-5093(02)00841-9.

[9] Zhang Z, Wang Z, Jiang Z, Tan H, Han D, Guo Y, et al. Effect of post-weld heat treatment on microstructure evolution and pitting corrosion behaviour of UNS S31803 duplex stainless steel welds. Corrosion Science. 2012;62:42-50. http://dx.doi. org/10.1016/j.corsci.2012.04.047.

[10] Yang $Y$, Wang Z, Tan H, Hong J, Jiang Y, Jiang L, et al. Effect of a brief post-weld heat treatment on the microstructure evolution and pitting corrosion of laser beam welded UNS S31803 duplex stainless steel. Corrosion Science. 2012;65:472-480. http:// dx.doi.org/10.1016/j.corsci.2012.08.054.

[11] Lippold JC, Koseki DJ. Welding metallurgy and weldability of stainless steels. Hoboken: John Wiley; 2005. 376 p.

[12] Yousefieh M, Shamanian M, Saatchi A. Influence of heat input in pulsed current GTAW process on microstructure and corrosion resistance of duplex stainless steel welds. Journal of Iron and Steel Research International. 2011;18(9):65-69. http://dx.doi. org/10.1016/S1006-706X(12)60036-3.
[13] Moura VS, Lima LD, Pardal JM, Kina AY, Corte RRA, Tavares SSM. Influence of microstructure on the corrosion resistance of the duplex stainless steel UNS S31803. Materials Characterization. 2008;59(8):1127-1132. http://dx.doi.org/10.1016/j. matchar.2007.09.002.

[14] Devendranath Ramkumar K, Mishra D, Vignesh MK, Ganesh Raj B, Arivazhagan N, Naren SV, et al. Metallurgical and mechanical characterization of electron beam welded superduplex stainless steel UNS 32750. Journal of Manufacturing Processes. 2014;16(4):527-534. http://dx.doi.org/10.1016/j. jmapro.2014.07.011.

[15] Pilhagen J, Sandstrom R. Influence of nickel on the toughness of lean duplex stainless steel welds. Materials Science and Engineering A. 2014;602:49-57. http://dx.doi.org/10.1016/j. msea.2014.01.093.

[16] Migiakis K, Papadimitriou GD. Effect of nitrogen and nickel on the microstructure and mechanical properties of plasma welded UNS S32760 super-duplex stainless steels. Journal of Materials Science. 2009;44(23):6372-6383. http://dx.doi. org/10.1007/s10853-009-3878-9.

[17] Garzon C, Ramirez A. Growth kinetics of secondary austenite in the welding microstructure of a UNS S32304 duplex stainless steel. Acta Materialia. 2006;54(12):3321-3331. http://dx.doi. org/10.1016/j.actamat.2006.03.018.

[18] Vandervoort G. Metallography: principles and practice. 2nd ed. Ohio: ASM International; 2000.

[19] Lancaster J. Metallurgy of welding. 6th ed. Cambridge: Wood Head Publishing; 1999. 464 p.

[20] Ogawa T, Koseki T. Effect of composition profiles on metallurgy and corrosion behaviour of duplex stainless steel weld metals. Welding Research Supplement, May 1989, 1181s-1191s

[21] Sathiya P, Aravindan S, Soundararajan R, Noorul Haq A. Effect of shielding gases on mechanical and metallurgical properties of duplex stainless-steel welds. Journal of Materials Science. 2009;44(1):114-121. http://dx.doi.org/10.1007/s10853-0083098-8.

[22] Mendoza BI, Maldonado ZC, Albiter HA, Robles PE. Dissimilar welding of super duplex stainless steel/HSLA steel for offshore applications joined by GTAW. Engineering. 2010;2(7):520-528. http://dx.doi.org/10.4236/eng.2010.27069.

[23] Sieurin H, Sandstrom R. Austenite reformation in the heataffected zone of duplex stainless steel 2205. Materials Science and Engineering A. 2006;418(1-2):250-256. http://dx.doi. org/10.1016/j.msea.2005.11.025.

[24] Hsieh R, Liou HY, Pan YT. Effects of cooling time and alloying elements on the microstructure of the Gleeble-simulated heat affected zone of $22 \% \mathrm{Cr}$ duplex stainless steels. Journal of Material Science Performance. 2000;10(5):526-536. http:// dx.doi.org/10.1361/105994901770344665.

[25] Du JK, Wang CH, Wang KC, Chen KK. TEM analysis of 2205 duplex stainless steel to determine orientation relationship between M23C 6 carbide and austenite matrix at $950{ }^{\circ} \mathrm{C}$. Intermetallic. 2014;45:80-83. 
[26] Muthupandi V, Bala Srinivasan P, Seshadri SK, Sundaresan S. Effect of weld metal chemistry and heat input on the structure and properties of duplex stainless steel welds. Materials Science and Engineering A. 2003;358(1-2):9-16. http://dx.doi. org/10.1016/S0921-5093(03)00077-7.

[27] Hagen IV, Keller M. Interrelation between fabrication processes and mechanical properties of AF 22 duplex tubes. Journal of Materials for Energy System. 1983;5(2):88-96. http://dx.doi. org/10.1007/BF02833534

[28] Liu LH, Lu X, Jin X. Phase transformation and mechanical properties in laser continuous heat treatment welds. Materials \& Design. 2011;32(4):2269-2276. http://dx.doi.org/10.1016/j. matdes.2010.11.016.
[29] Udayakumar T, Raja K, Tanksale Abhijit A, Sathiya P. Experimental investigation on mechanical and metallurgical properties of super duplex stainless steel joints using friction welding processes. Journal of Manufacturing Processes. 2013;15(4):558-571. http:// dx.doi.org/10.1016/j.jmapro.2013.06.010.

[30] Gun RN, editor. Duplex stainless steels: microstructure, properties and applications. Cambridge: Abington Publishing; 1997.

[31] DNV Rules. Submarine pipelines systems: offshore standard DNV-OSF101. Norway: Det Norske Veritas Publisher; 2007.

[32] American Society for Testing and Materials - ASTM. ASTM E8-04: standard test methods for tension testing of metallic materials. West Conshohocken: ASTM; 2004. 